\title{
Assessment of sustainable foreign economic activity strategies of Russian corporations
}

\author{
Evgeniy Stepanov ${ }^{1, *}$, Dmitri Pletnev², and Van Duc Pham ${ }^{3,4}$ \\ ${ }^{1}$ South Ural State University (National Research University), 76, Lenina str., 454080, Chelyabinsk, \\ Russia \\ ${ }^{2}$ Chelyabinsk State University, 129, Br. Kashirinykh str., 454001, Chelyabinsk, Russia \\ ${ }^{3}$ Graduate Academy of Social Sciences, 477, Nguyen Trai str., Thanh Xuan district, Hanoi, 10000, \\ Vietnam \\ ${ }^{4}$ Vietnam Academy of Social Sciences, No1, Lieu Giai Str., Badinh Dist, Hanoi, 10000, Viet Nam
}

\begin{abstract}
In modern economic literature, several strategies for the development of enterprises are considered at the theoretical level. However, as an independent form of strategy, foreign economic activity strategy is not considered, or not enough attention is paid to it. The purpose of the article is to identify the strategies of foreign economic activity of Russian enterprises in the oil and gas, metallurgical industries, and the food industry, based on their annual reports and ratings of Russian analytical agencies. The objectives of the study are, firstly, the development of a methodology for assessing the results of strategies for foreign economic activity, and secondly, the analysis of strategies for foreign economic activity, as a result of their commodity market, resource market, technological, integration, and financial investment strategies. As a result of the study, the features of Russian corporations' strategies of foreign economic activity have been revealed. Their trajectories are shown in the "commodity item - country" coordinate system.
\end{abstract}

\section{Introduction}

From a macroeconomic point of view, exports are a strategically important factor in every national economy's economic growth integrated into world trade. Consequently, issues related to the development strategy of foreign economic relations are relevant for each country. Exports represent the value of all sales abroad by export-oriented enterprises of the national economy. From a microeconomic perspective, a firm that only operates in the national market risks losing it to more vigorous domestic and foreign competitors. Therefore, the company faces the task of entering the world market even if it has never been involved in international trade. Furthermore, if it has exported earlier, the task is to maintain its position in the world economy. Consequently, strategies for foreign economic activity and the choice of the best strategies from them are significant for any enterprise that will enter the world market or that is already working in it.

In the economic literature, there are the following approaches to assessing enterprise

\footnotetext{
*Corresponding author: stepanovea@susu.ru
} 
development strategies. Bilovodska, Kholostenko, Mandrychenko \& Volokitenko [1] developed recommendations for improving the business strategy of chemical enterprises, based on which a methodology for choosing the most objective strategic alternative was developed. They proposed to expand the market share of the enterprise and introduce the intensity of sales of products for various types of products; consider the features of the legal regulation of the chemical industry in the production of innovative products; maintain the trend towards lower production costs; look for ways to increase the company's profits by controlling costs and increasing sales. Borowski [2] proposes the development of an innovative strategy for enterprises using bamboo as a resource. He argues that bamboobased innovation is becoming eco-innovation that sustains green efficiency and a circular economy. Khrystyna and others [3] provide methodological and practical recommendations for developing and implementing a strategic management system for enterprise innovation. Hoa, Anh \& Phong [4] investigate the relationship between manufacturing strategy and competitiveness in 25 Vietnamese enterprises. Based on the research, they offer recommendations for the effective implementation of manufacturing strategies and technology to improve competitiveness. Chemirbayeva, Malgarayeva \& Azamatova [5] analyze the economic strategy for diversifying light industry enterprises' activities based on the implementation of innovative approaches to management, including organizational design project management, costs, and human capital. Spillan, Parnell, Panibratov \& Yukhanaev [6] investigate the influence of organizational potential on an enterprise's development strategy. Arora \& De [7] argue that Latin American firms must first adopt a sustainable product strategy to enter international markets successfully. Behmiri, Rebelo, Guveia \& Antonio [8] analyze the impact of the size, age and production efficiency of winemaking firms in Portugal on export strategy. Edeh, Obodoechi \& Ramos-Hidalgo [9] assess the impact of innovation strategies on exports in developing countries. Wang \& Wei [10] analyze the strategies of Chinese exporters. In their view, exporters are very active in their strategies concerning their export product range and portfolio of destinations. They regularly introduce new products and ditch some old ones to have a range of products for their target markets while maintaining their core product strategy. Wang and Ma [11] consider firms with two types of export strategies: expansion-oriented and exit-oriented. The goal of "running firms" is to break out of the imperfect institutional environment in their country, creating additional costs for doing business. Such exporters are more sensitive and responsive to changes in the environment, although they do not increase their learning level to the same extent as exporters focused on expansion. Karapidis, Chrysoshaw and Karipidou [12], based on a study of 83 Greek agricultural exporting firms, assessed the impact of production chain parameters on exports. The most critical parameters are the quality of raw materials, purchase costs and producer prices.

The problem lies in the fact that in modern studies, the assessment of the strategies of enterprises' foreign economic activity is not considered at all, or not enough attention is paid to it.

\section{Materials and methods}

The statistical base of the study is data on the leading Russian exporting enterprises of the analytical center "Expert" for 2013-2018, namely: the number of importing countries of the enterprise's products and the number of traded commodity items at the level of the first four characters of the commodity nomenclature of foreign economic activity.

The research methodology is based on identifying the strategy of foreign economic activity of the enterprise through the assessment of their commodity-market, resourcemarket, technological, integration and financial-investment strategies of enterprises. We used the annual reports posted on twelve companies' official websites in the oil and gas, 
metallurgical and food industries.

Within the framework of the studied enterprises, the trajectories of the strategies of their foreign economic activity in the "commodity position - country" coordinate system are revealed. The $\mathrm{X}$-axis will represent the number of export commodity items (G) of the enterprise, and the $\mathrm{Y}$-axis - the number of countries to which the enterprise's products (C) are exported in a certain time. Point $\mathrm{Y} 1(\mathrm{G}, \mathrm{C})$ in this coordinate system will mean the result of the enterprise's strategy of foreign economic activity in the Y1 year. We will consider a change in the position of a point in the system as a change in an enterprise's foreign economic strategy.

For example, point $Y_{1}(5,7)$ means that the result of the foreign economic strategy of the enterprise in a particular time (usually a year) is the export of five commodity items to seven countries of the world economy (Fig. 1)

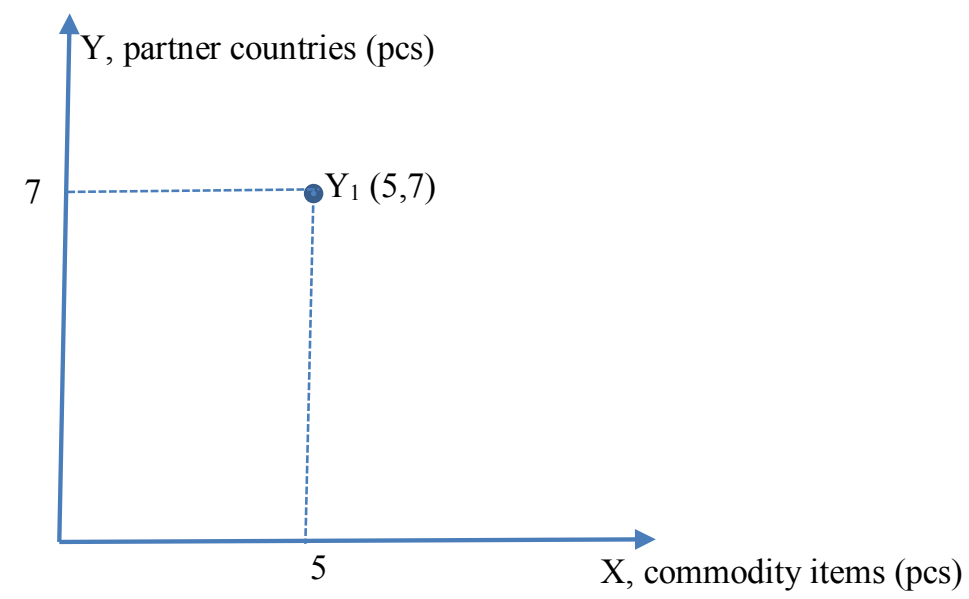

Fig. 1. Foreign economic strategy of the enterprise in the "commodity position - country" coordinate system.

\section{Results}

\subsection{Assessment of strategies for foreign economic activity of oil and gas corporations}

Let us consider the results of the strategies of foreign economic activity of the leading oil and gas enterprises included in the TOP-200 leading exporters of Russia according to the Expert magazine for the period 2013-2018. Their dynamics is shown in Fig. 2 (a, b, c, d).

The commodity and market strategy of the Gazprom corporation is to expand new sales markets for gas and oil products, as well as electricity. The commodity part of the strategy is to increase the range of products for oil and gas processing. From the point of view of the resource-market strategy, the goal is to compensate for oil and gas production with reserves of industrial categories and develop the resource base in promising territories. The resource strategy's market component is discovering new oil and gas fields in Russia and the CIS countries, Europe, Southeast Asia, Africa, the Middle East, and South America. The enterprise's technological strategy consists of the constant search, development, and implementation of new technologies to explore, produce, and process oil and gas. The enterprise's integration strategy is to integrate "forward", that is, accelerated development of the manufacturing sector and delivery of products to end consumers. Gazprom has achieved 
the best results in terms of the integration strategy. The company's financial and investment strategy is to form a conservative budget that can cope with risks in the financial markets. In particular, this budget considers the risks of unauthorized gas withdrawal and non-receipt of payment for the delivered supplies.
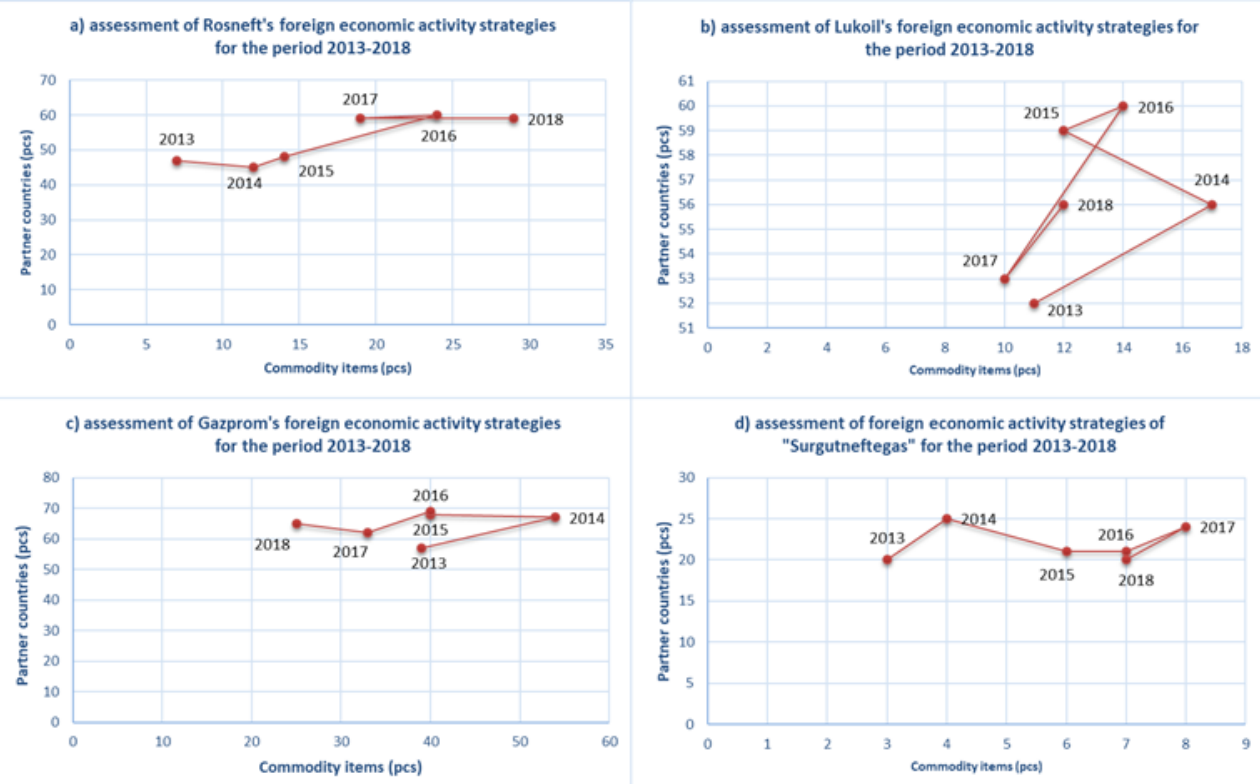

Fig. 2. Strategies for foreign economic activity of oil and gas corporations.

The Lukoil enterprise's commodity-market strategy was initially based on the global idea of becoming a leading transnational corporation in the world economy. The strategy's goal is to expand new markets for its products in the countries of the world and produce not only oil and gas but also refined products. The resource-market strategy consisted of developing new deposits in Russia in the Yamal-Nenets Autonomous Okrug, but also in Uzbekistan, Azerbaijan, and Iraq. The technology strategy aims to develop technologies to increase the oil recovery rate, which has remained low since the Soviet period at $28 \%$. The enterprise's integration strategy is also in the "forward" integration, the accelerated development of the mining and the refining sector through the construction of new oil refineries both in Russia and abroad. The company's financial and investment strategy aims to increase financial indicators, increase profitability, ensure sustainable growth of free cash flow even in the absence of an increase in oil prices, and a possible increase in business tax burden.

The product and market strategy of Rosneft is based on the geographical diversification of sales channels (jet fuel, marine fuel, lubricants, and changing the product basket following market trends (production of new brands of products - bitumen, lubricants. The resource and market strategy consist of in geological exploration and production of hydrocarbons both in the Russian territory - on the shelf and onshore of the Far East, Western and Eastern Siberia, Timan-Pecher, Central Russia, and abroad, namely in Brazil, Norway, Venezuela, Iraq, Myanmar, and Canada. The strategy is to create a high-tech business of a new format for the service of oil products, which will ensure the enterprise's strategic objectives and the best economic efficiency in the oil sector. The enterprise's integration strategy is aimed "upward" by creating its gas stations, refineries in Russia, Germany, Belarus, and Ukraine. 48 distribution channels are located in the Russian Federation and Belarus, Mongolia, Kyrgyzstan, Armenia, Georgia, and Abkhazia. The 
financial and investment strategy is aimed at a stable accumulation of positive cash flow, a logical reduction in financial liabilities, and dividends following the best practices in the oil sector.

The product and market strategy of Surgutneftegas is to increase the types of refined products with high environmental and operational properties, diversify the supply of products to new markets, increase sales of high-margin products, attract and retain consumers by providing quality products. The enterprise's resource-market strategy is expressed in the strengthening and development of the mineral resource base through geological exploration and the purchase of new territories and associated gas production. The technological strategy is to expand the scope of the introduction of modern equipment and technologies that increase geological exploration efficiency and the development of oil and gas fields, the introduction of energy-saving and energy-efficient solutions. The enterprise's integration strategy is expressed in the "upward" movement by creating its filling stations and the expansion of related services, the creation of its own thermal and power plants. The financial and investment strategy of the Surgutneftegas enterprise is to maintain and maintain at the required level all types of financial resources through a cost reduction program, development of its own securities market, and increase in product profitability.

\subsection{Assessment of strategies for foreign economic activity of oil and gas corporations}

Dynamics of the strategies of foreign economic activity of the leading metallurgical enterprises included in the TOP-200 leading exporters of Russia according to the Expert magazine for the period 2013-2018. shown in fig. 3 (a, b, c, d).
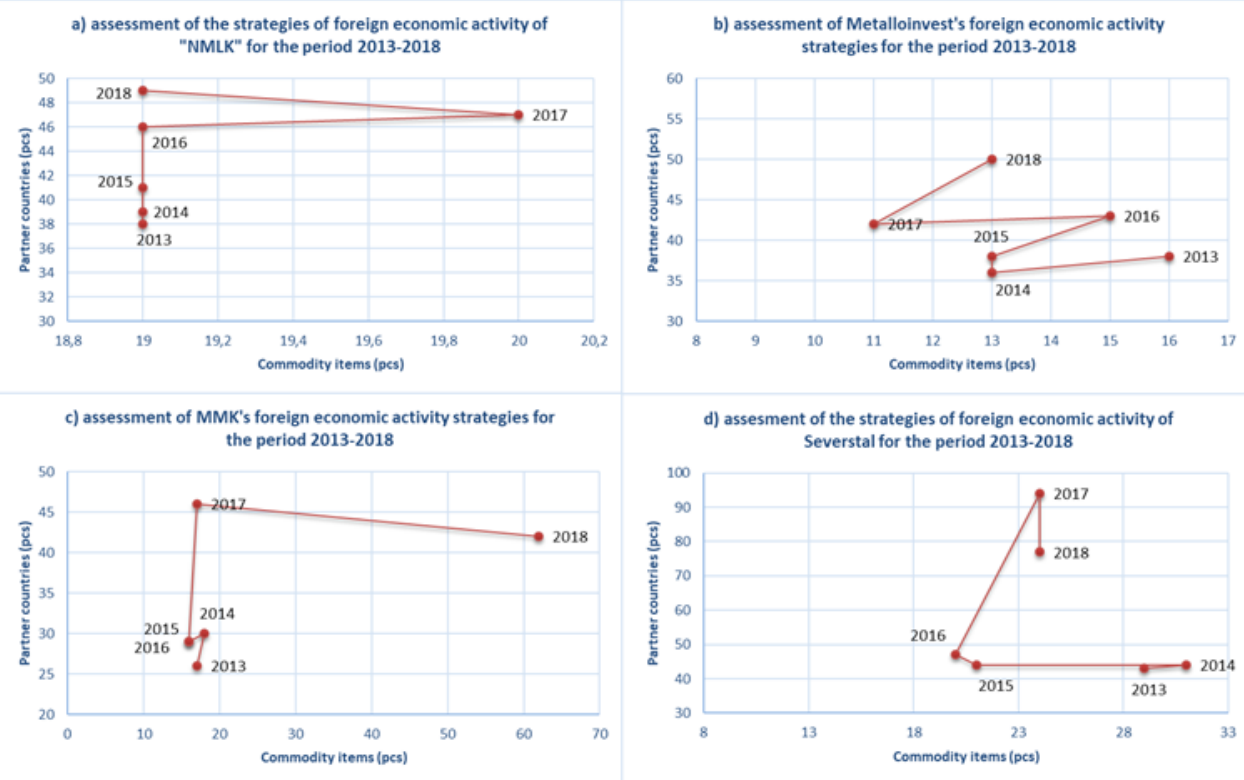

Fig. 3. Strategies of foreign economic activity of metallurgical corporations.

Commodity component The Novolipetsk Metallurgical Plant (NMLK) product-market strategy is to increase the range of high-quality steel products and increase the production of products with high added value. The strategy's market component is the growth of geographic markets for the sale of metallurgical products both in Russia and in the 
countries of the world economy. The resource-market strategy of NMLK is expressed in the growth of iron ore production at its resource bases Stoilensky GOK, Dolomit and Stagdok, located in the Lipetsk region, which is used both at the enterprise and other metallurgical enterprises, agriculture and road facilities. The technological strategy is to move towards the best technological practices, allowing to achieve world leadership in production costs and steel quality. As for the integration strategy, NMLK seeks to acquire production assets in Russia, the United States and Europe. The company's financial and investment strategy is aimed at increasing its shareholder value and a stable positive cash flow. The strategy's investment part is to expand its iron ore mining capacities and acquire enterprises for the production of high value-added steel products both in Russia and abroad.

MMK's product and market strategy's market component is to increase the share of sales in the domestic market compared to the foreign one. The strategic initiatives portfolio consists of the following theses: "Just-in-time sales" and "Supplier No. 1 for the most demanding customers of the automotive industry in the domestic market. The commodity component of the strategy is to expand the range of high-quality steel products. The resource-market strategy is expressed in the conclusion of long-term contracts for the supply of iron ore with the Kazakhstani company ERG (Rudny) and the Metalloinvest enterprise (Kursk Magnetic Anomaly). Part of the strategy is the insufficient supply of raw materials by $18-20 \%$ due to the volatility of iron ore prices. The technological strategy of MMK "Is to improve technologies that will strengthen the position of a low-cost producer in the metallurgical industry by introducing the world's best practices and the best available technologies. MMK's integration strategy is aimed at purchasing Russian raw material assets and finishing assets in Russia and other wounds. In 2010, MMK's financial and investment strategy also increased its shareholder value and a stable positive cash flow.

The commodity component of Severstal's product and market strategy is the continuous development of new types of products that meet next-generation infrastructure projects' requirements. The strategy's market component is to separate the assortment into massmarket products and narrow-use products adapted to customers. The resource-market strategy is to improve the quality of iron ore and coal, modernize equipment for enrichment of raw materials at its resource bases Karelsky Okatysh (Karelia), Olkon (Murmansk Oblast), Vorkutaugol (Komi Republic), Yakovlevsky Rudnik (Belgorod region). The enterprise is $80 \%$ self-sufficient in coking coal, $130 \%$ in iron ore, and $80 \%$ in electricity. Severstal's technological strategy is to develop technologies that will reduce the cost of steel by $10 \%$ compared to competitors. The integration strategy is expressed in creating a vertically integrated business model with high-quality, modern mining and metallurgical enterprises. Severstal's financial and investment strategy is to increase cash receipts and ensure maximum profitability for shareholders.

The product and market strategy of Metalloinvest is to expand the range and improve the performance of steel products, expand sales markets and further improve the quality of rolled steel, including high-quality long products and thick plates. The strategy's market component is to expand the geography of sales of ore and steel products to metallurgical plants both in Russia and in the countries of Western and Eastern Europe, Asia and North Africa. Resource-market strategy - to be a manufacturer and supplier of high-quality iron ore raw materials for our own needs and third-party metallurgical enterprises. The enterprise's technological strategy is expressed in the development of technologies that would improve the quality characteristics of products. The integration strategy is expressed in creating a vertically integrated organization with high-quality, modern mining and metallurgical assets. The financial and investment strategy is to increase the company's shareholder value and maintain a positive cash flow. The company's investment strategy is to invest in projects such as energy efficiency, reduction of atmospheric emissions, and laboratory equipment development. 


\subsection{Assessment of foreign trade strategies of food industry corporations}

Let us consider the results of the strategies of foreign economic activity of the leading food industry enterprises included in the TOP-200 leading exporters of Russia according to the Expert magazine for the period 2013-2018. Their dynamics is shown in Fig. 4 (a, b, c, d).
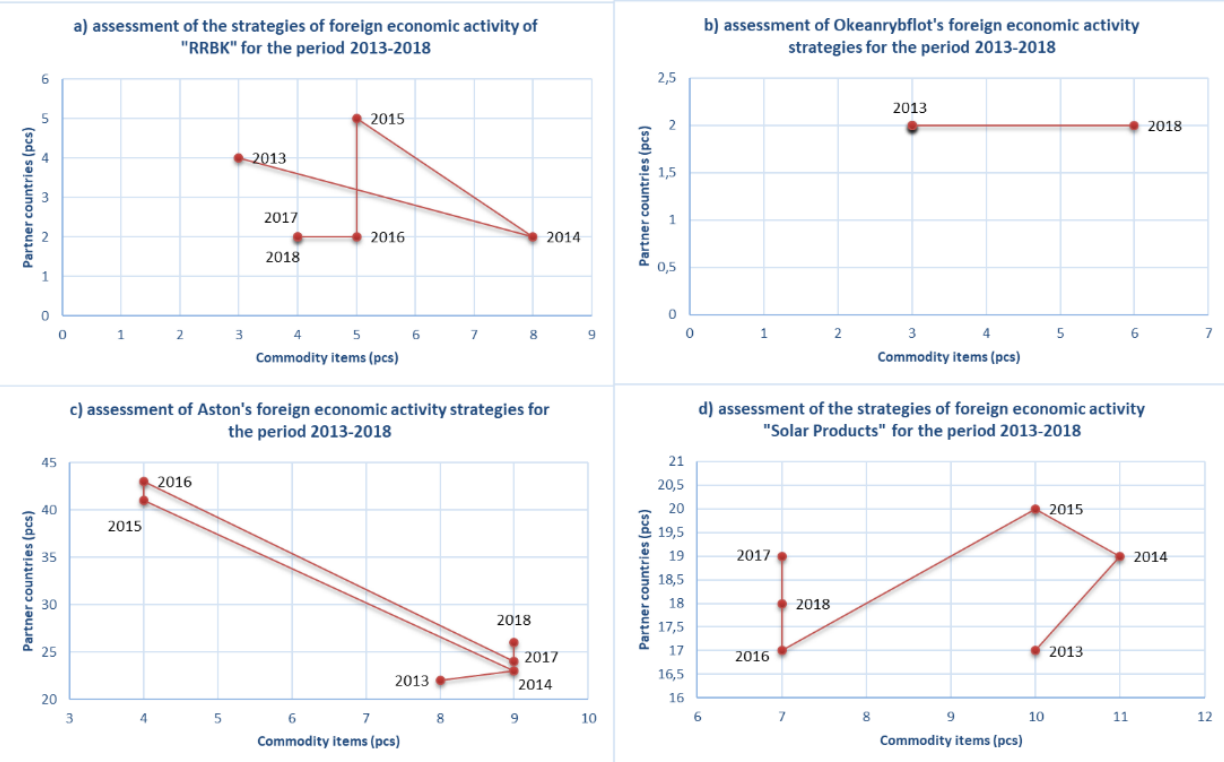

Fig. 4. Strategies of foreign economic activity of food industry corporations.

The commodity-market strategy of the corporations "Aston" and "Solar Products" is to increase the range of production of food, feed products, food ingredients and cereals. The companies strive to expand the geography of their sales in the international market. The main partner countries are Egypt, Turkey, Algeria, Afghanistan, Bangladesh, Vietnam, ECO and CIS countries. The financial, investment, and technological strategy is to invest in the development of agriculture and the food industry in Russia, expanding production capacities and introducing technological solutions that make it possible to increase enterprises' energy and resource efficiency. The resource-market strategy is to grow all the main crops that are the basic raw materials for producing and exporting their products: wheat, corn, sunflower, barley, peas, etc. The integration strategy is aimed at creating a vertically integrated structure for the production of food products.

The commodity-market strategy of the fish companies "Russian Fish Industrial Company" and "Okeanrybflot" is to catch pollock, herring and squid based on state quotas, in their high-quality processing and increase the share of exports of processed products to the countries of the Asia-Pacific region, mainly to Japan and China. The resource-market strategy is to increase the amount of fish caught in the Bering and Okhotsk seas. The integration strategy aims to create a vertically integrated structure of fish catch and processing plants in Russia. The technological strategy is to replace old fishing vessels with new ones and improve technologies to produce products with a higher degree of processing. The financial and investment strategy is to invest in constructing and acquiring new processing plants in Murmansk, the Far East, and Petropavlovsk-Kamchatsky. 


\section{Discussion and Conclusion}

The strategies of foreign economic activity of Russian corporations in the long term are planned in nature. In the short term, strategies can be intuitive. The enterprise's foreign economic strategy is a derivative of its commodity-market, resource-market, technological, integration, and financial investment strategies.

The foreign economic aspect of the commodity market strategy of the oil and gas sector enterprises is to increase new sales markets (countries of the world economy) and change the food basket following market trends, that is, with foreign buyers' needs. The grocery basket includes crude oil, natural gas, liquefied natural gas, and oil and gas refined products. The external economic component of the resource-market and financialinvestment strategies is expressed in investments in geological exploration and development of new oil and gas fields in the CIS countries, Europe, Southeast Asia, Africa, the Middle East, and South America. The foreign economic component of the integration and financial and investment strategies of oil and gas enterprises is the integration "forward", expressed in creating their gas stations, construction, and purchase of oil and gas processing plants, thermal and power plants in the countries of the world economy. From the point of view of technological strategy, the foreign economic activity aims to import modern digital technologies, robotics, crewless aerial vehicles to improve the efficiency of several business processes in the oil and gas sector.

The foreign economic aspect of the metallurgical sector enterprises' commodity-market strategy is to increase new sales markets (countries of the world economy) and change the food basket following global trends, that is, with the needs of foreign buyers. The food basket includes iron ore, coking coal, steel products, and finished products. Despite the reduction of commodity positions in some enterprises, the strategy aimed to expand the range of stable product groups and improve their operational characteristics. The purpose of the foreign economic component of the resource-market strategy of metallurgical enterprises (except for MMK) is to increase sales of processed iron ore to the world economy countries. MMK, not having its own iron ore deposits, imports ore from Kazakhstan. The foreign economic component of the integration and financial and investment strategies is both horizontal and vertical integration. Horizontal integration is expressed in investments in the acquisition and construction of metallurgical plants in Europe, the USA, and Turkey. The goal of vertical integration is to move "forward" through investments in foreign metallurgical enterprises of a higher value-added. From the point of view of technological strategy, the foreign economic activity aims to import modern digital technologies, robotics, and crewless aerial vehicles to increase the efficiency of several business processes in the metallurgical sector. Most metallurgical enterprises implement a unified information system for managing financial and economic activities "SAP S / 4HANA", developed by the German software manufacturer "SAP SE".

The foreign economic strategy of food industry enterprises is to increase the range of food and fish production. Enterprises are striving to expand the geography of their sales in the international market and create vertically integrated structures.

\section{Acknowledgement}

The reported study was funded by RFBR and VASS, project number 20-510-92006. 


\section{References}

1. O. Bilovodska, A. Kholostenko, Z. Mandrychenko, O. Volokitenko, Journal of Optimization in Industrial Engineering 14(12), 89-96 (2021) DOI: 10.22094/JOIE.2020.677820.

2. P. Borowski, Journal of Innovation and Entrepreneurship 10(3) (2021) DOI: 10.1186/s13731-020-00144-2.

3. Z. Khrystyna, P. Kateryna, M. Olha, D. Olena, Journal of Optimization in Industrial Engineering 14(7), 119-127 (2021) DOI: 10.22094/JOIE.2020.677838

4. H.T. Hoa, P.C. Anh, L.T. Phong, Organizations and Markets in Emerging Economies 11(22), 482-503 (2021) DOI: 10.15388/OMEE.2020.11.44

5. M. Chemirbayeva, Z. Malgarayeva, A. Azamatova, Entrepreneurship and Sustainability Issues 8(2), 1083-1102 (2020) DOI:10.9770/jesi.2020.8.2(65)

6. J.E. Spillan, J.A Parnell, A. Panibratov, A. Yukhanaev, European Journal of International Management 15(1), 1-26 (2021) DOI: 10.1504/EJIM.2021.111913

7. P. Arora, P. De, Journal of World Business 55(4) (2020) DOI: 10.1016/j.jwb.2020.101094

8. N. Behmiri, J. Rebelo, S. Gouveia, P. António, International Journal of Wine Business Research 31(3), 419-440 (2019) DOI: 10.1108/IJWBR-07-2018-0032

9. J. Edeh, D. Obodoechi, E. Ramos-Hidalgo, Technological Forecasting \& Social Change 158 (2020) DOI: 10.1016/j.techfore.2020.120167

10. W. Wang, H. Ma, Journal of World Business 53(4), 581-592 (2018) DOI: 10.1016/j.jwb.2018.04.002

11. Y. Wang, W. Wei, Transnational Corporations Review 12(1), 10-23 (2020) DOI: 10.1080/19186444.2020.1724483

12. P. Karipidis, P. Chrysochou, I. Karypidou, British Food Journal 122(4), 1305-1320 (2020) DOI: 10.1108/BFJ-05-2019-0376. 